\section{Regards sur l'économie allemande}

Bulletin économique du CIRAC

$111 \mid 2013$

Varia

\title{
Immobilier : hausses de prix dans le résidentiel urbain
}

Solène Hazouard

\section{(2) OpenEdition}

1 Journals

Édition électronique

URL : http://journals.openedition.org/rea/4628

DOI : 10.4000/rea.4628

ISSN : 1965-0787

Éditeur

CIRAC

Édition imprimée

Date de publication : 1 décembre 2013

Pagination : 34-35

ISSN : 1156-8992

\section{Référence électronique}

Solène Hazouard, «Immobilier : hausses de prix dans le résidentiel urbain », Regards sur l'économie

allemande [En ligne], 111 | décembre 2013, mis en ligne le 17 décembre 2013, consulté le 15

septembre 2020. URL : http://journals.openedition.org/rea/4628

Ce document a été généré automatiquement le 15 septembre 2020.

(c) CIRAC 


\title{
Immobilier : hausses de prix dans le résidentiel urbain
}

\author{
Solène Hazouard
}

Dans les villes allemandes, l'immobilier résidentiel a connu une telle hausse depuis 2010 qu'il pourrait bien être surévalué. C'est la conclusion à laquelle parvient la Bundesbank dans son rapport mensuel d'octobre 2013.

\section{Particulièrement concerné : le « top 7 » des villes allemandes}

2 Un fossé semble s'être creusé entre la campagne et les agglomérations, au sein desquelles les hausses de prix se révèlent, selon la Bundesbank, particulièrement difficiles à justifier. En effet, alors que la hausse enregistrée sur l'ensemble du territoire s'élève à $8,25 \%$, maisons et appartements confondus, dans les plus grandes villes, les appartements se sont renchéris de plus de $25 \%$. Dans le «top 7 », composé de Berlin, Düsseldorf, Francfort-sur-le-Main, Hambourg, Cologne, Munich et Stuttgart, les écarts de prix pourraient même atteindre $20 \%$ par rapport au niveau théorique résultant des seuls facteurs démographiques et économiques.

3 Ces hausses de prix, stimulées par une forte demande, résultent de l'attrait du marché immobilier allemand, particulièrement stable en comparaison internationale et actuellement plus rentable que les placements financiers (voir REA 110/13). Dans ce contexte, la Bundesbank s'oppose à une limitation des loyers susceptible de dissuader les investisseurs de construire. Car malgré la reprise de la construction, enclenchée en 2010, l'offre d'appartements demeure insuffisante dans les grandes villes attractives. 


\section{INDEX}

Mots-clés : immobilier, logement, prix, loyer, revenu, aménagement du territoire, politique communale, marché 